\title{
GENDER DALAM DAKWAH UNTUK PEMBANGUNAN (Potret Keterlibatan Perempuan dalam Politik)
}

\author{
Ulfatun Hasanah \\ Mahasiswa Pascasarjana UIN Walisongo \\ Email: ulfatunhasanah92@gmail.com
}

\begin{abstract}
Gender issues are an issue that demands social and cultural construction justice between men and women. In the demands of this construction, the balance of functions, status, and nature of the sexes is expected to be realized. Instead, da'wa and development is a construction of the changes that take place in society from certain socio-cultural conditions toward something that is considered more valuable. In addition it can also be interpreted as an effort to alleviate backwardness. Therefore, all, gender, da'wa and development are a reciprocal correlation between one another. The emergence of gender injustice issues or gender discrimination due to social construction process in society. Yet Islam and the Constitution of 45 countries have guaranteed equality of access for women and men. Therefore, enhancing the role of women and men in gendered development as an integral part of national development has significance in the effort to achieve harmonious harmony between men and women or to achieve gender equality and justice in various areas of life and development. The results of this study, trying to reveal da'wa gender in development should not be the same role between men and women, there are areas of their own that can be done by men and women in da'wa and development process.
\end{abstract}

Isu gender merupakan suatu isu yang menuntut keadilan konstruksi sosial maupun kultural antara kaum laki-laki dengan perempuan. Dalam tuntutan konstruksi ini, keseimbangan fungsi, status, dan hakekat antar jenis kelamin diharapkan dapat direalisasikan. Sebaliknya, dakwah dan pembangunan merupakan suatu konstruksi perubahan yang terjadi di masyarakat dari kondisi sosio-kultural tertentu menuju ke arah sesuatu yang dianggap lebih bernilai. Oleh karena itu semua, gender dan pembangunan adalah suatu korelasi timbal balik antara satu dengan yang lain. Munculnya isu ketidakadilan gender atau diskriminasi gender akibat adanya proses kontruksi sosial di dalam masyarakat. Padahal Islam dan UUD 45 negara telah menjamin kesetaraan akses perempuan dan laki-laki. Oleh karena itu, peningkatan peranan perempuan dan laki-laki dalam dakwah dan pembangunan yang berwawasan gender sebagai bagian integral dari pembangunan nasional, mempunyai arti penting dalam upaya untuk mewujudkan kemitrasejajaran yang harmonis antara laki-laki dengan perempuan atau mewujudkan kesetaraan dan keadilan gender dalam berbagai bidang kehidupan dan pembangunan. Hasil penelitian ini, berusaha menampakkan gender dalam dakwah dan pembangunan tidak harus sama peran antara laki-laki dan perempuan, ada wilayah-wilayah sendiri yang bisa dilakukan laki-laki dan perempuan dalam pelaksanaan dakwah dan pembangunan.

Kata Kunci: Gender, Kontruksi Sosial, Kombangpar. 


\section{A. Pendahuluan}

Terminologi dakwah dan pembangunan merupakan isu penting yang tidak pernah berhenti dibahas baik di negara terbelakang, negara berkembang, sampai dengan negara maju. Walaupun konteks yang dibicarakan dan cara yang digunakan mereka berbeda-beda, akan tetapi pada dasarnya tujuan yang diharapkan semua sama, yakni membawa negaranya masing-masing dari keadaan sebenarnya saat ini menuju keadaan normatif yang dianggap lebih baik. ${ }^{1}$ Biasanya, dakwah diarahkan pada hal spiritual, pembangunan lebih pada persoalan infrastruktur.

Tidak dapat disangkal lagi bahwa partisipasi masyarakat di dalam kegiatan dakwah dan pembangunan sangatlah penting. Menurut Kartasasmita (1955) "pembangunan memang dapat juga berjalan denganmengandalkan kekuatan yang ada pada pemerintah ....... namun hasilnya tidak akansama jika dibandingkan dengan pembangunan yang mendapat dukungan danpartisipasi rakyat". Karena partisipasi masyarakat ${ }^{2}$ tersebut sangat penting, Di dalam Garis-Garis Besar Haluan Negara (GBHN) Indonesia disebutkan bahwa partisipasi aktif segenap lapisan masyarakat dalam pembangunan harus makin meluas dan merata. Adapun pengertian partisipasi disini diwujudkan dalam memikul beban, tanggungjawab dalam pelaksanaan dan menerima kembali hasil-hasil pembangunan. Meskipun istilah partisipasi sudah menjadi jargon politik yang pewujudannya dalam proses pembangunan ini diinginkan oleh semua orang, tapi sebagai istilah, perkataan partisipasi belum mendapatkan batasan pengertian yang jelas.

${ }^{1}$ Afriandi Setiawan, dkk, Gender dan Pembangunan, diakses 2011, dalam https://arifcintaselvia.wordpress.com/kuliah/teori-pembangunan/gender-dan-pembangunan/.

${ }^{2}$ Menilik asal usul istilah komunikasi pembangunan, pertama kali diciptakan pada tahun 1972 oleh Nora, Quebral. Ia mendefiniskan komunikasi pembangunan sebagai: the art and science of human communication linked to a society's planned transformation from a state of poverty to one of dynamic socioeconomic growth that makes for greater equity and the larger unfolding of individual potential (sebuah seni dan ilmu pengetahuan komunikasi manusia yang berhubungan dengan sebuah transformasi sosial yang direncanakan dari suatu negara yang miskin kepada satu dinamika pertumbuhan ekonomi-sosial yang menciptakan keadilan yang merata dan membentangkan individu yang seluas-luasnya).Komunikasi hadir pada semua upaya yang bertujuan terarah untuk membawa ke arah perubahan. Tetapi ini tidak berarti bahwa komunikasi itu faktor yang paling menentukan. Komunikasi hanyalah salah satu dari sekian komponen faktor-faktor yang paling penting adalah yang menentukan organisasi struktural masyarakat, kondisi politik, ekonomi, dan sosial yang menempati batas-batas tempat perubahan bisa terjadi. Menurut Royal D. Colle terdapat tujuh benang yang mempunyai sumbangsih dalam komunikasi pembangunan, salah satunya yaitu The Community Participation Thread (benang partisipasi masyarakat).Secara historis, gagasan lahirnya Komunikasi Pembangunan Partisipatif sendiri diilhami oleh pemikiran intelektual dari Amerika Latin oleh Paulo Freire, kemudian diikuti oleh Luis Ramiro Beltran, dan Juan Diaz Bordenave. Istilah Participatory Communication sendiri pertama kali digunakan secara resmi dalam sebuah seminar di Amerika Latin (1978) yang disponsori oleh Center for Advanced Studies and Research for Latin America.Jadi, komunikasi pembangunan partisipatif adalah suatu aktifitas yang direncanakan yang didasarkan pada proses-proses partisipatif di satu sisi, dan pemanfaatan media komunikasi dan komunikasi tatap muka di sisi lain, dengan tujuan untuk memfasilitasi dialog diantara pemangku kepentingan yang berbeda, yang berkisar pada perumusan masalah atau sasaran pembangunan bersama, mengembangkan dan melaksanakan atau menjabarkan seperangkat aktivitas yang memberi kontribusi untuk mecari solusi yang didukung bersama. 
Adanya keiikutsertaan masyarakat dalam setiap tahapan pembangunan, sering dikaitkan dengan upaya menumbuhkan rasa memiliki ("sense of ownership" atau "sense of belonging") terhadap sarana atau prasarana yang dibangun. Dengan adanya rasa memiliki ini pada gilirannya akan menghasilkan pembangunan yang berkelanjutan (sustainability).

Pembangunan pada prinsipnya harus memberikan keadilan dan kemakmuran kepada semua masyarakat, kepada laki-laki maupun perempuan, kepada yang kaya maupun yang miskin (Teori Fungsionalisme, Talcot Parson). ${ }^{3}$ Fakta yang ada sekarang justru pembangunan semakin mempertajam kesenjangan keadilan sosial antara masyarakat miskin dengan masyarakat yang kaya, antara perempuan dengan laki-laki, antara kelompok yang berkuasa dengan kelompok masyarakat biasa. Hal ini terlihat adanya ketidakadilan gender dalam pembangunan.

Lalu, Benarkah perempuan termarginalkan? Benarkah adanya ketidakadilan gender dalam pembangunan?Bertitik tolak dari problem yang ada di masyarakatbahwaadanya diskriminasi perempuan atau perempuan termarginalkan. Penulis berusaha mencoba mengupasnya lebih dalam.

\section{B. Selayang Pandang Gender}

Isu gerakan gender berasal dari Barat pada sekitar \pm tahun 1980 (diresmikan) sedangkan tahun 1960-an sudah ada tetapi belum diresmikan yang sering disebut dengan istilah feminisme. ${ }^{4}$ Istilah genderdiperkenalkan oleh para

${ }^{3}$ Teori Struktural-Fungsional. Teori ini muncul di tahun 30-an sebagai kritik terhadap teori evolusi. Teori ini mengemukakan tentang bagaimana memandang masyarakat sebagai sebuah sistem yang saling berkaitan. Teori ini mengkui adanya keanekaragaman dalam kehidupan sosial. Dalam kondisi seperti itu, dibuatlah suatu sistem yang dilandaskan pada konsensus nilai-nilai agar terjadi adanya interelasi demi sesuatu yang dinamakan harmoni, stabilitas dan keseimbangan (equilibrium). Sistem ini mensyaratkan aktor dalam jumlah memadai, sehingga fungsi dan struktur sesorang dalam sistem menentukan tercapainya stabilitas atau harmoni tersebut. Ini berlaku untuk sistem sosial: agama, pendidikan, struktur politik, sampai rumah tangga, dalam hal ini termasuk mengenai gender. Sosialisasi fungsi struktur tersebut dilakukan dengan institusionalisasi, melalui norma-norma yang disosialisasikan. Secara rinci teori ini berisi: (1) masyarakat memiliki kelembagaan yang mirip organ tubuh biologi, saling terkait dan tergantung satu dengan yang lain, (sistem), (2) setiap lembaga masyarakat mumpunyai fungsi yang jelas dan khas, untuk melakukan tugas menunjang kestabilan dan kemajuan masyarakat, (3) functional emperatif, yaitu AGIL (Adoption to the environment, goal attaintment, integration and latency), Lembaga ekonomi untuk A, Pemerintah untuk G, Lembaga Hukum dan Agama untuk I dan LembagaPendidikan dan Keluarga untuk L.

${ }^{4}$ Gerakan feminisme merupakan gerakan konflik sosial yang dimotori oleh para pelopor feminisme dengan tujuan mendobrak nilai-nilai lama (patriarki) yang selalu dilindungi oleh kokohnya tradisi struktural fungsional. Gerakan feminism modern di Barat dimulai pada tahun 1960-an yaitu pada saat timbulnya kesadaran perempuan secara kolektif sebagai golongan tertindas. Menurut Skolnick: Some feminists denounced the family as a trap that turned women into slaves (beberapa feminis menuduh keluarga sebagai perangkap yang membuat para perempuan menjadi budak-budak). Gerakan feminisme yang berdasarkan model konflik berkembang menjadi gerakan-gerakan feminisme liberal, radikal, dan sosialis atau Marxisme. Untuk memahami konsep feminisme berikut diuraikan berdasarkan sejarah berkembangnya gerakan feminisme yang mencakup dua gelombang: (1) Gerakan gelombang pertama, lebih pada gerakan filsafat di Eropa yang dipelopori oleh Lady Mary Wortley Montagu dan Marquis de Condorcet yang pada Tahun 1785, suatu perkumpulan masyarakat ilmiah untuk perempuan pertama kali didirikan di Middelburg (Selatan Belanda). Seorang aktivis sosialis utopis bernama Charles Fourier pada 
ilmuwan sosial untuk menjelaskan perbedaan perempuan dan laki-laki yang bersifat bawaan sebagai ciptaan Tuhan dan yang bersifat bentukan budaya yang dipelajari dan disosialisasikan sejak kecil. ${ }^{5}$

Istilah gender pertama kali di perkenalkan oleh Robert Stoller (1968). Secara etimologi (bahasa), kata "jender" berasal dari bahasa Inggris, gender berarti “jenis kelamin", sedangkan menurut bahasa Arab gender berarti "مسوة جسية". Sedangkan secara terminologi (istilah), gender adalah suatu konsep kultural yang berupaya membuat pembedaan (distinction) dalam hal peran, perilaku, mentalitas, dan karakteristik emosional antara laki-laki dan perempuan yang berkembang dalam masyarakat. ${ }^{6}$ Istilah gender belum masuk dalam perbendaharaan kata Kamus Besar Bahasa Indonesia. Tetapi dalam pemakaian berikutnya istilah ini selalu dikaitkandengan budaya. Istilah gender lebih banyak menunjuk kepada perbedaan status dan perananlaki-laki dan perempuan yang terbentuk dalamproses sosial dan budaya yang panjang. ${ }^{7}$

Gender - A way of looking at societywhich focuses on women'sroles and responsibilities in relation to those of men.

Gender - is not a property of individuals but an ongoing interaction between actors and structures with tremendous variation across men"s and women"s lives "individually over the life course and structurally in the historical context of race and class. (Ferree 1990 dalam Lloyd et al. 2009: p.8)

Di dalam buku yang berjudul Sex and Gender yang ditulis oleh Hilary M. Lips, mengartikan bahwa gender adalah harapan-harapan budaya terhadap laki-laki danperempuan. Hal ini dapat dilihat, misalnya bahwa perempuan dikenal dengan lemah lembut, cantik, emosional dan keibuan. Sementara laki-laki sebaliknya, yaitu dianggapkuat, rasional, jantan dan perkasa. Ciri-ciri dari sifat itu merupakan sifat yang dapat dipertukarkan, misalnya ada laki-laki yang lemah lembut, ada perempuan yang kuat, rasional dan perkasa. Perubahan ciri dari sifat-sifattersebut dapat terjadi dari waktu ke waktu dan dari tempat ke tempat yang lain. ${ }^{8}$

Tahun 1837 memunculkan istilah feminisme yang kemudian tersebar ke seluruh Eropa dan Benua Amerika. Publikasi John Stuart Mill dari Amerika dengan judul The Subjection of Women pada Tahun 1869 yang melahirkan feminisme Gelombang Pertama. (2) Feminisme gelombang kedua, dimulai pada Tahun 1960, dengan terjadinya liberalisme gaya baru dengan diikutsertakannya perempuan dalam hak suara di parlemen. Era Tahun 1960 merupakan era dengan mulai ditandainya generasi "baby boom" (yaitu generasi yang lahir setelah perang dunia ke-2) menginjak masa remaja akhir dan mulai masuk masa dewasa awal. Pada masa inilah, masa bagi perempuan mendapatkan hak pilih dan selanjutnya ikut dalam kancah politik kenegaraan.

${ }^{5}$ Herien Puspitawati, “Konsep, Teori dan Analisis Gender”, dalam jurnal Departemen Ilmu Keluarga dan Konsumen Fakultas Ekologi Manusia- Institut Pertanian Bogor 2013, h. 1.

${ }^{6}$ Azyumardi Azra,Kajian Tematik Al-Qur'an Tentang Kemasyarakatan, (Bandung: Angkasa, 2008), h. 315 .

${ }^{7}$ Sinulingga, R. dalam Jurnal Wawasan, Juni, Volume 12, Nomor 1. Medan: USU 2006, h. 47.

${ }^{8}$ M. Fakih, Analisis Gender dan Transformasi Sosial, (Yogyakarta: Pustaka Pelajar, 1996), h. 8-9. 
Dalam implementasinya, terjadi kerancuan dalam memahami gender dan seks. Pengertian gender itu berbeda dengan pengertian jenis kelamin (sex). Tabel berikut ini menyajikan perbedaan konsep gender dan jenis kelamin:

Tabel 1. Perbedaan sex dan gender ${ }^{9}$

\begin{tabular}{|c|c|c|c|}
\hline No & Aspek & Gender & Jenis Kelamin(Sex) \\
\hline 1. & Dasar & Konstruksi sosial. & Takdir \\
\hline 2. & Pencirian & Persepsi kultur (non-biologis) & Biologis \\
\hline 3. & $\begin{array}{l}\text { Status yang } \\
\text { dibentuk }\end{array}$ & $\begin{array}{l}\text { Feminin, maskulin. } \\
\text { Contohnya: } \\
\text { a. Perempuan itu dikenal } \\
\text { lemah lembut, cantik, } \\
\text { emosional, dan keibuan, } \\
\text { sedangkan laki-laki dianggap } \\
\text { kuat, rasional, jantan, dan } \\
\text { perkasa. } \\
\text { b.Sebagai konsekuensi dari hasil } \\
\text { kesepakatan masyarakat, maka } \\
\text { pembagian peran laki-laki } \\
\text { adalah mencari nafkah dan } \\
\text { bekerja di sektor publik, } \\
\text { sedangkan peran perempuan } \\
\text { di sektor domestik dan } \\
\text { bertanggung jawab masalah } \\
\text { rumah tangga. }\end{array}$ & $\begin{array}{l}\text { Perempuan, laki-laki } \\
\text { Contohnya: } \\
\text { Laki-laki memiliki penis, } \\
\text { jakala (kala menjing), dan } \\
\text { memproduksi sperma, } \\
\text { sedangkan perempuan } \\
\text { memiliki rahim dan saluran } \\
\text { untuk melahirkan, } \\
\text { memproduksi telur, } \\
\text { memiliki vagina, dan } \\
\text { mempunyai alat menyusui. }\end{array}$ \\
\hline 4. & Peran sosial & $\begin{array}{l}\text { a. Peran sosial dapat } \\
\text { berubah: Peran istri sebagai } \\
\text { ibu rumah tangga dapat } \\
\text { berubah menjadi pencari } \\
\text { nafkah, disamping menjadi } \\
\text { istri juga. } \\
\text { b. Peran sosial dapat } \\
\text { dipertukarkan: Untuk saat-saat } \\
\text { tertentu, bisa saja suami tidak } \\
\text { memiliki pekerjaan sehingga } \\
\text { tinggal di rumah mengurus } \\
\text { rumah tangga, sementara istri } \\
\text { bertukar peran untuk bekerja } \\
\text { mencari nafkah bahkan sampai } \\
\text { ke luar negeri. Atau Sifat-sifat } \\
\text { perempuan dan laki-laki dapat } \\
\text { dipertukarkan, artinya ada } \\
\text { laki-laki yang memiliki sifat } \\
\text { lemah lembut dan keibuan dan }\end{array}$ & $\begin{array}{l}\text { a.Peran reproduksi tidak } \\
\text { dapat berubah: Sekali } \\
\text { menjadi perempuan dan } \\
\text { mempunyai rahim, maka } \\
\text { selamanya akan menjadi } \\
\text { perempuan dan } \\
\text { sebaliknya. } \\
\text { b. Peran reproduksi } \\
\text { tidak dapat } \\
\text { dipertukarkan: tidak } \\
\text { mungkin laki-laki } \\
\text { melahirkan dan } \\
\text { perempuan membuahi. }\end{array}$ \\
\hline
\end{tabular}

${ }^{9}$ Afriandi Setiawan, dkk, Gender dan Pembangunan, diakses 2011, dalam https://arifcintaselvia.wordpress.com/kuliah/teori-pembangunan/gender-dan-pembangunan/. 


\begin{tabular}{llll}
\hline No & Aspek & \multicolumn{1}{c}{ Gender } & Jenis Kelamin(Sex) \\
\hline & & $\begin{array}{l}\text { ada juga perempuan yang kuat, } \\
\text { rasional, dan perkasa. }\end{array}$ & \\
\hline 5. & Jangkauan & Kelompok sosial tertentu. & Universal, seluruh dunia. \\
\hline
\end{tabular}

\section{Gender Sebagai Proses Kontruksi Sosial di Masyarakat}

Kontruksi sosial ${ }^{10}$ merupakan pembentukan dari sistem konseptual kebudayaan dan linguistik. Kontruksi sosial juga bertujuan membuat dunia bermakna kepada yang lain. Makna tercipta dari sistem alih kode, aturan atau kesepakatan maupun tanda secara historis. Kontruksi peran gender adalah bagaimana peran gender dibentuk dari kebudayaan dan disosialisasikan.

Gender juga merupakan alat analisis yang baik untuk memahami persoalan diskriminasi terhadap kaum perempuan secara umum. Ditegaskan bahwa gender adalah pembagian laki-laki dan perempuan yang dikontruksi secara sosial dan budaya. Dan ternyata, perbedaan gender antara laki-laki dan perempuan terjadi melalui proses yang panjang, melalui proses sosialisasi, penguatan, kontruksi, sosial budaya bahkan melalui kekuasaan negara. Sedemikian panjang dan lamanya proses "genderisasi" secara sosial budaya tersebut sehingga lambat laun perbedaan gender antara laki-laki dan perempuan sebagai kontruksi sosial budaya menjadi seolaholah ketentuan dari Tuhan, atau bersifat kodrati dan biologis yang tidak dapat diubah lagi. Artinya, ada anggapan sebagian besar masyarakat yang namanya kodrat wanita adalah hasil kontruksi sosial dan budaya atau gender. Gender mempengaruhi keyakinan manusia serta budaya masyarakat tentang bagaimana seharusnya laki-laki dan perempuan berpikir dan bertindak sesuai dengan ketentuan sosial tersebut. Pembedaan yang ditentukan oleh aturan masyarakat dan bukan biologis itu dianggap sebagai ketentuan Tuhan.

Perbedaan peran gender yang merupakan bentukan masyarakat tersebut disosialisasikan terus menerus melalui pendidikan baik secara langsung maupun tidak langsung dalam: keluarga (orang tua), sekolah (guru), negara (pembuat kebijakan, penguasa), dan dimasyarakat (tokoh masyarakat, pemuka agama, media massa, dan lain-lain). Misalnya saja sejak kecil anak sudah dibiasakan dengan mainan yang berbeda, untuk anak laki-laki mobil-mobilan, senjata, robot, dan sebagainya, sedangkan perempuan diberikan boneka, peralatan rumah tangga, dan pelatan masak. Pemberian mainan tersebut secara tidak langsung mengajarkan kepada anak tentang perbedaan peran masing-masing, bahwa laki-laki menjadi gagah, pemberani, dan kelak menjadi penanggung jawab keluarga. Sedangkan kepada perempuan diharapkan bisa mempunyai sifat keibuan yang pintar

\footnotetext{
${ }^{10}$ Kontruksi sosial lahir dari pemikiran Peter L. Berger, dituangkan dalam karya yang terkenal, yaitu Inovation to Sociology (1963) dan The Social Contructions of Reality (1966) yang ditulis bersama temannya, Thomas Luckmann. Dalam bukunya tersebut, dinyatakan bahwa realitas terbentuk secara sosial, oleh karenanya sosiologi sebagai ilmu pengetahuan harus menganalisa bagaimana proses tersebut terjadi.
} 
mengurus anak, masak dan mengurus rumah. Pendidikan dan pembiasaan demikian telah berlangsung lama dan turun temurun tanpa ada yang mempertanyakan, sehingga terjadi proses internalisasi yang lancar tanpa hambatan. Tidak mengherankan jika kemudian perbedaan yang merupakan hasil bentukan masyarakat tersebut dipahami sebagai kodrat. Oleh karena itu pula masyarakat sangat memegang teguh 'aturan-aturan' yang membedakan peran perempuan dan laki-laki. Namun, di sisi lain banyak pula yang 'melanggar' dan pada akhirnya masyarakat bisa menerima pula.

Hubungan atau relasi antar jenis kelamin (perempuan dan laki-laki) atau relasi gender dipengaruhi oleh pandangan yang ada antara keduanya. Posisi perempuan, maupun posisi laki-laki sedemikian rupa, dibangun dalam beragam level, yakni:

1. Di tingkat keluarga, institusi keluarga merupakan ruang awal peran dan idiologi gender diperkenalkan. Contohnya, keluarga yang mendambakan anak laki-laki menyiapkan segala perlengkapan bayi yang belum lahir dengan warna biru sebagai warna tegas, dan merah bila anaknya perempuan. Pemberian alat permainan yang stereotip pada anak-anak juga merupakan pandangan gender. Anak laki-laki pastinya tidak diharapkan untuk bermain boneka atau memasak. Pada komunitas tertentu anak laki-laki tidak dituntut untuk bisa memasak atau melakukan pekerjaan kerumahtanggaan. Sementara anak perempuan diajarkan untuk membantu ibu di rumah dan lain-lain. Pola pengasuhan dan pendidikan ini akan mempengaruhi pandangan sang anak kelak dalam memilih dan menyesuaikan profesi dan keahliannya. Ini karena mereka terdidik dan diperlakukan demikian. Dan demikian seterusnya.Keluarga berperan melanggengkan bentuk dan relasi gender, baik yang adil maupun yang timpang.

2. Di tingkat sekolah/pendidikan formal, isi ajaran pendidikan di sekolah menjadi salah satu dasar pola perilaku dan pandangan mengenai posisi, peran, tanggung jawab dan fungsi yang berbeda antara perempuan dan laki-laki. Ini bisa dilihat dari kurikulum pengajaran dan cara mendidik di sekolah. Ini tidak hanya dialami oleh peserta didik, namun juga pendidik atau guru. Ada banyak bukti pembedaan perlakuan antara guru laki-laki dan guru perempuan. Banyak bukubuku pelajaran yang dibuat dengan bahasa dan ilustrasi yang melanggengkan stereotip peran dan kedudukan perempuan dan laki-laki. Misalnya, ada buku yang mengajarkan bahwa kegiatan anak perempuan membantu ibu di rumah setelah pulang sekolah sementara anak laki-laki digambarkan bermain bola.

3. Di tingkat masyarakat, masyarakat sebagai wadah pencetak budaya, nilai, norma, dan tradisi yang mencerminkan pola relasi antara perempuan dan lakilaki. Pemaknaan dan pemberian posisi, peran, dan tanggungjawab akan masingmasing jenis kelamin dan gender dibentuk dalam bahasa masyarakat sesuai dengan tingkat kepantasan. Masyarakat seolah memiliki kriteria dan hukum 
mengenai apa yang pantas, layak dan wajar juga yang tidak layak, tidak pantas dan di luar kewajaran yang dilakukan oleh laki-laki, juga oleh perempuan.

4. Di tingkat negara/ pemerintah, banyak program pemerintah dan kebijakan Negara yang dibangun dengan kontruksi gender yang stereotip. Misalnya, Posyandu merupakan program kesehatan anak yang dibangun untuk perempuan, dengan asumsi perempuan atau ibu merupakan pihak yang bertanggung jawab pada kondisi kesehatan keluarga (anak). Sementara banyak pelatihan teknis (seperti bidang pertanian) hanya bisa diakses laki-laki, seolah tidak ada perempuan yang menggeluti bidang ini. Namun saat ini gencar dikampanyekan gerakan keterlibatan ayah di kegiatan Posyandu. Hal ini telah berlangsung di beberapa wilayah Indonesia, meskipun masih sangat terbatas. Perubahan kebijakan ini tentu melihat kebutuhan bahwa perempuan semakin dituntut untuk memasuki dunia publik karena juga dibutuhkan pemikirannya, sementara laki-laki juga perlu peka dan lebih intensif terlibat pada kegiatan yang bersifat domestik, karena keduanya memiliki nilai yang sama. Termasuk menakar nilai kegiatan produktif (menghasilkan pendapatan) dan reproduktif. Ini artinya perspektif kebijakan yang stereotip akan menciptakan program yang sangat stereotip dan menjadi pembenaran dan pelanggengan. Negara dan pemerintah menjadi salah satu institusi yang bertanggung jawab pada pola relasi gender pada masyarakatnya. ${ }^{11}$

\section{Kesetaraan Gender dalam Dakwah}

Kita ketahui bahwa salah satu misi Islam adalah pembebasan manusia dari berbagai bentuk anarki dan ketidakadilan. Islam sangat menekankan pada keadilan di semua aspek kehidupan. Keadilan ini tidak akan tercapai tanpa membebaskan golongan masyarakat lemah dan marjinal dari penderitaan. Hal ini ditegaskan dalam al-Qur'an, bahwa orang-orang yang beriman diperintahkan untuk berjuang membebaskan golongan masyarakat lemah dan tertindas. ${ }^{12}$

Rasulullah SAW juga mengajarkan kesetaraan dan keadilan gender. Pada masa jahiliyyah perempuan sempat mendapatkan perlakukan bias gender seperti: diperkosa, simpanan laki-laki, beban ganda, kekerasan nafsu laki-laki, dan sebagainya. Setelah Islam datang, masa Rasulullah SAW perempuan dan laki-laki posisinya setara. Pada masa Rasulullah dan sahabatnya, sekian banyak perempuan/isteri yang bekerja. Ada yang bekerja sebagai perias pengantin, seperti Ummu Satim binti Malhan yang merias pengantin antara lain: Shafiyah bin Huyay, isteri Nabi Muhammad SAW. Bahkan isteri Nabi Muhammad SAW Zainab binti Jahesy juga aktif bekerja sampai pada menyimak kulit binatang, dan hasil usahanya itu beliau bersedekah. Selain itu, Siti Khatijah juga sebagai bisnis woman. Raithah,

\footnotetext{
${ }^{11}$ Anisa Siti Aisah, dkk, “Gender Sebagai Kontruksi Sosial”, diakses Jum'at 10 Juni 2016, dalam http : // tangan-malaikat.blogspot .com/ 2016/ 06/ makalah- gender-sebagai-kontruksi-sosial.html?m=1.

${ }^{12}$ Jihan Abdullah, "Kesetaraan Gender Dalam Islam”, dalam jurnal Musawa, Vol. 1 (1), 2009, h. 4.
} 
isteri sahabat Nabi, Abdullah Ibnu Mas'ud, sangat aktif bekerja, karena suami dan anaknya ketika itu, tidak mampu mencukupi kebutuhan hidup keluarga ini. Bahkan pada masa Raja Sulaiman, Ratu Bilqis menjadi sudah menjadi Ratu satu jagad dunia. Setelah Rasulullah meninggal, realita yang ada bias gender mulai muncul kembali. ${ }^{13}$

Dalam al-Qur'an sangat menjunjung kesetaraan dan keadilan gender ${ }^{14}$ meskipun hanya tersirat (tekstual) saja. ${ }^{15}$ Yang ada hanya ciri-ciri/ prinsip-prinsip kesetaraan gender dalam al-Qur'an. Banyak ayat menjelaskan tentang prinsipprinsip kesetaraan gender. Nasaruddin Umar (2001: 247-268) mencoba mengkompilasinya sebagai berikut: (1) Laki-laki dan perempuan sama-sama sebagai hamba (QS. al-Hujurat: 13), (2) Laki-laki dan perempuan sama-sama

${ }^{13}$ Bias gender muncul lagi disebabkan, ketika penafsiran yang terkait dengan perempuan selalu saja didefinisikan melalui konsep fikih, perempuan dipandang inferior dengan landasan tafsir yang mengandung bias misoginis. Hal tersebut dapat jadi karena adanya beberapa hal, antara lain ialah sebagai berikut: (1) Pemahaman terhadap pengertian gender dan seks dalam mendefinisikan peran seringkali belum pas. (2) Metode penafsiran yang selama ini digunakan, masih banyak mengacu pada pendekatan tekstual, bukan kontekstual; sebagai konsekuensi qaidah ushul yang biasa dijadikan pegangan jumhur ulama tafsir (al ibrah bi umum al lafdzi, la bi khusus as sabab), (3) Umumnya mufassir adalah kaum laki-laki, (4) Banyak dikesankan bahwa kitab suci Al-Qur'an banyak memihak laki-laki dan mendukung sistem patriarkhi, yang oleh kalangan feminis dipandang bisa merugikan perempuan, dan (5) Pengaruh kisah Israiliyat yang berkembang luas di kawasan Timur Tengah.Bias gender tidak hanya terjadi dalam memahami atau menafsirkan ayat-ayat, melainkan juga muncul dalam pemahaman hadis Nabi Muhammad SAW. Bahkan, bias gender juga ditemukan dalam penafsiran banyak literatur Islam klasik (kitab kuning), terutama dalam penafsiran kitab-kitab fiqh yang pada umumnya sering dianggap mutlak kebenarannya (Subhan, 2010: 24).Jika kita perhatikan uraian di atas, maka pandangan yang menginterpretasikan bahwa Islam menganggap wanita itu lemah, tidak cerdas, tidak layak menjadi pemimpin, derajat wanita di bawah tingkatan laki-laki, dan pandangan-pandangan lain yang meminggirkan wanita pada dasarnya karena kesalahan dalam menginterpretasikan teks-teks agama yang bersifat diskriminatif. Oleh karena itu, penafsiran ini perlu diluruskan dan perlu dicarikan solusinya, atau dengan kata lain, perlu adanya reinterpretasi (Khariri, 2009: 6).Menurut Umar bias gender dalam penafsiran teks-teks kitab suci Al-Qur'an dapat ditelusuri (lihat Umar 2001: 268-290).

${ }^{14}$ Kesetaraan dan keadilan gender adalah suatu kondisi yang adil (equity) dan setara (equality) dalam hak, kesempatan dan hubungan kerjasama antara laki-laki dan perempuan, dengan kondisi saling mendukung/ melengkapi dan saling menghormati/ menghargai. Kesetaraan gender: Kondisi perempuan dan laki-laki menikmati status yang setara dan memiliki kondisi yang sama untuk mewujudkan secara penuh hak-hak asasi dan potensinya bagi pembangunan di segala bidang kehidupan. Definisi dari USAID menyebutkan bahwa "Gender Equality permits women and men equal enjoyment of human rights, socially valued goods, opportunities, resources and the benefits from development results.3.5 (kesetaraan gender memberi kesempatan baik pada perempuan maupun laki-laki untuk secara setara/sama/sebanding menikmati hak-haknya sebagai manusia, secara sosial mempunyai benda-benda, kesempatan, sumberdaya dan menikmati manfaat dari hasil pembangunan). Keadilan gender: Suatu kondisi adil untuk perempuan dan laki-laki melalui proses budaya dan kebijakan yang menghilangkan hambatan-hambatan berperan bagi perempuan dan laki-laki. Definisi dari USAID menyebutkan bahwa "Gender Equity is the process of being fair to women and men. To ensure fairness, measures must be available to compensate for historical and social disadvantages that prevent women and men from operating on a level playing field. Gender equity strategies are used to eventually gain gender equality. Equity is the means; equality is the result.3.5 (Keadilan gender merupakan suatu proses untuk menjadi fair baik pada perempuan maupun laki-laki. Untuk memastikan adanya fair, harus tersedia suatu ukuran untuk mengompensasi kerugian secara histori maupun sosial yang mencegah perempuan dan laki-laki dari berlakunya suatu tahapan permainan. Strategi keadilan gender pada akhirnya digunakan untuk meningkatkan kesetaraan gender. Keadilan merupakan cara, kesetaraan adalah hasilnya).

15 Nasaruddin Umar, Argumen Kesetaraan Gender Perspektif Al-Qur'an, (Jakarta: Paramadina, 2001), h. 247-268. 
sebagai khalifah (QS. al-Baqarah: 30), (3) Laki-laki dan perempuan sama-sama menerima perjanjian primordial (QS. al-A`râf: 172), (4) Adam dan Hawa adalah aktor yang sama-sama aktif terlibat dalam drama kosmis (QS. al-A`raf: 22), dan(5)Laki-laki maupun perempuan sama-sama berhak meraih prestasi dalam kehidupannya (QS. al-Nahl: 97). Misi pokok kitab suci al-Qur'an diturunkan ialah untuk membebaskan manusia dari berbagai bentuk diskriminasi dan penindasan, termasuk diskriminasi seksual. Sehingga bila terdapat penafsiran yang mengarah kepada nilai ketidakadilan, maka penafsiran tersebut perlu diteliti dan dikaji kembali (direinterpretasi).

Dalam kaitannya dengan persoalan relasi laki-laki dan perempuan, prinsip dasar Al-Qur'ân sesungguhnya memperlihatkan pandangan yang egaliter. Menurut Asghar, Al-Qur'ân lah yang pertama kali memberikan mereka (perempuan) hak-hak yang sebelumnya tidak pernah mereka dapatkan dalam aturan yang legal. ${ }^{16}$

Islam sendiri bukan agama patriarki. ${ }^{17}$ Islam tidak mengajarkan bahwa kedudukan perempuan berada di bawah seorang laki-laki. Islam mengajarkan bahwa seorang perempuan ketika menikah maka tanggung jawab atas dirinya berada pada diri laki-laki yang menjadi suaminya. Hadits menunjukkan bahwa Islam memberikan penghormatan yang besar terhadap perempuan, karena sebaikbaiknya laki-laki muslim adalah yang berbuat baik kepada istrinya. Islam memberikan kehormatan yang tinggi bagi para muslimah. Tidak ada kewajiban bagi mereka untuk mencari nafkah. Bukannya menggambarkan wanita sebagai orang yang lemah dan tukang membebani laki-laki, tetapi ini adalah penghormatan Islam kepada perempuan sehubungan dengan tugas mereka yang amat vital di dalam rumah keluarganya.

Islam memberikan kewajiban dan hak yang sama bagi laki-laki maupun perempuan, namun laki-laki diberikan satu tingkat lebih tinggi dibanding perempuan bukan untuk merendahkan tapi dalam sebuah rumah tangga laki-laki menjadi imam yang memiliki tanggungjawab serta tugas yang tidak mudah dalam menjaga istri dan anak-anaknya kelak. ${ }^{18}$ Sebagaimana firman Allah SWT dalam QS. Al-Hujurat 13:

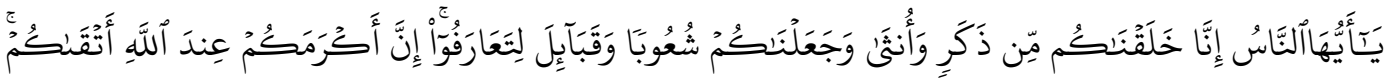

$$
\begin{aligned}
& \text { إِنَّ ألَّهَ عَلِيمُ خَبِيرُ }
\end{aligned}
$$

\footnotetext{
${ }^{16}$ Nasaruddin Umar,Argumen Kesetaraan Gender Perspektif Al-Qur'an,h. xxxiv-xxxv.

${ }^{17}$ Budaya patriarki merupakan budaya dimana laki-laki mempunyai kedudukan lebih tinggi dari perempuan. Dalam budaya ini, ada perbedaan yang jelas mengenai tugas dan peranan perempuan dan lelaki dalam kehidupan bermasyarakat, khususnya dalam keluarga. Laki-laki sebagai pememimpin atau kepala keluarga memiliki otoritas yang meliputi kontrol terhadap sumber daya ekonomi, dan suatu pembagian kerja secara seksual dalam keluarga. Hal ini menyebabkan perempuan memiliki akses yang lebih sedikit di sektor publik dibandingkan lelaki. Patriarki adalah istilah yang dipakai untuk menggambarkan sistem sosial dimana kaum laki-laki sebagai suatu kelompok mengendalikan kekuasaan atas kaum perempuan.

${ }^{18}$ Anonim, "Apa Arti Budaya Patriarki?", dalam http://id. Answers.yahoo.com/question/index?_e_pi_=7\%2CPAG_ID10\%2C3573569691.
} 
Artinya:"Hai manusia, sesungguhnya Kami menciptakan kamu dari seorang laki-laki dan seorang perempuan dan menjadikan kamu berbangsa-bangsa dan bersuku-suku supaya kamu saling kenal-mengenal. Sesungguhnya orang yang paling mulia di antara kamu di sisi Allah ialah orang yang paling takwa diantara kamu. Sesungguhnya Allah Maha Mengetahui lagi Maha Mengenal." (QS. Al-Hujurat: 13) ${ }^{19}$

Berdasarkan ayat di atas, laki-laki dan perempuan sama-sama sebagai hamba. Tugas pokok hamba adalah mengabdi dan menyembah. Ini dapat dipahami dalam firman-Nya: "Dan tidaklah Aku menciptakan jin dan manusia kecuali untuk menyembah-Ku" (QS. al-Dzâriyât: 56). Dalam kapasitas manusia sebagai hamba, tidak ada perbedaan antara laki-laki dan perempuan. Perbedaan yang dijadikan ukuran untuk memuliakan atau merendahkan derajat mereka hanyalah nilai ketaqwaannya. Prestasi ketaqwaan dapat diraih oleh siapa pun, tanpa memperhatikan perbedaan jenis kelamin, suku bangsa atau kelompok etnis tertentu. $^{20}$

\section{E. Gender dalam Dakwah dan Pembangunan}

Walaupun mencuatnya isu gender lebih disebabkan kerena gertakan dari kaum feminisme, namun pembangunan tetaplah hal yang universal. Oleh karena itu, bila tuntutan tersebut hanya mengacu pada substansi perempuan, maka akan menjadi pertanyaan balik bagi kaum laki-laki, kaum laki-laki akan menuntut hal yang sama. Oleh karena itu, maka gender merupakan suatu hal yang harus dipandang secara keseluruhan dalam pembangunan.

Apabila dibayangkan, hubungan antara gender dengan pembangunan terasa masih membingungkan. Padahal, bagaimanapun metode dan konsep pembangunan pasti akan diikuti atau berpengaruh pada kehidupan baik spesifik pada laki-laki, perempuan, atau keduanya. Oleh karena itu, pembahasan gender dengan pembangunan bukanlah hal yang dapat diapresiasi dengan sikap skeptis. Isu gender merupakan suatu isu yang menuntut keadilan konstruksi sosial maupun kultural antara kaum laki-laki dengan perempuan. Dalam tuntutan konstruksi ini, keseimbangan fungsi, status, dan hakekat antar jenis kelamin diharapkan dapat direalisasikan. Sebaliknya, pembangunan merupakan suatu konstruksi perubahan yang terjadi di masyarakat dari kondisi sosio-kultural tertentu menuju ke arah sesuatu yang dianggap lebih bernilai. Selain itu dapat juga diartikan sebagai usaha pengentasan keterbelakangan. Oleh karena itu, gender dan pembangunan adalah suatu korelasi timbal balik antara satu dengan yang lain.

\footnotetext{
2010), 518 .

${ }^{19}$ Depag RI, Al-Hidayah (Al-Qur'an Tafsir Per Kata Tajwid Kode Angka), (Jakarta: PT Kalim,

${ }^{20}$ Fadlan, “Islam, Feminisme, dan Konsep Kesetaraan Gender Dalam Al-Qur'an”, dalam Jurnal Karsa, Vol. 19 (2), 2011, h. 13.
} 
Kesejahteraan merupakan tujuan utama dari adanya pembangunan. Substansi dari kesejahteraan salah satunya dengan adanya keadilan. keadilan sendiri bukanlah hal yang dapat dengan mudah diperhitungkan secara matematis. Keadilan dalam ekonomi belum dapat dikatakan sebagai kesimpulan keadilan, melainkan baru sebatas substansi keadilan. Untuk itu, aspek manusia tidak dapat diabaikan, karena sudah hakekat manusia sebagai homo politicus. Lantas, pertanyaan yang muncul adalah tentang bagaimana cara pembenahan bila dari segi manusia dalam bersosial tidak ada kesejahteraan?. Mencoba mendalami isu ini, maka muncul pertanyaan baru, yakni apakah pembangunan yang tujuan utamanya untuk mencapai kesejahteraan mengabaikan atau hanya sekilas mengintip masalah gender? Inilah yang selalu dipertanyakan dan dituntut oleh para aktivis gender, khususnya kaum feminisme.

Melihat fakta yang ada selama ini ada, memang dapat dirasakan bahwa pembangunan yang dilakukan hanyalah mekanisme yang dilakukan oleh pihak kapitalis. Kesejahteraan yang menjadi tujuan utama dari pembangunan dirubah menjadi unsur pembangunan. Pembangunan sampai dewasa ini lebih meningkatkan dari segi infrastruktur dan ekonomi. Sektor keseimbangan dalam hal ini gender kurang diperhatikan. Hal ini disebabkan bahwa terdapat suatu penyimpangan dalam konsep pembangunan.

Akibatnya adalah gender mengalami eksklusi sosial yaitu proses yang menghalangi atau menghambat individu dan keluarga, kelompok dan kampung dari sumber daya yang dibutuhkan untuk berpartisipasi dalam kegiatan sosial, ekonomi dan politik didalam masyarakat dengan utuh. Maka terciptalah ketidaksetaraan gender atau ketidakadilan gender dalam pembangunan. ${ }^{21}$

Lalu, benarkah jika perempuantermarginalkan dalam pembangunan? Isu ini muncul akibat proses kontruksi sosial di dalam masyarakat. Peran perempuan pada urusan domestik. Beberapa artikel, jurnal, buku menyebutkan bahwa perempuan dalam pembangunan selama ini termarginalkan. Fakih (1999) menjelaskan ketidakadilan gender ${ }^{22}$ tersebut antara lain: 1) marginalisasi perempuan, 2) penempatan perempuan pada subordinat, 3) stereo type perempuan, 4) kekerasan (violence) terhadap perempuan, dan 5) beban kerja tidak proposional.

Isu ini, melahirkan pendekatan awal mencakup penargetan perempuan dalam perencanaan dan intervensi proyek yang berfokus pada perempuan sebagai

21 Setiawan, Afriandi dkk, Gender dan Pembangunan, diakses 2011, dalam https://arifcintaselvia.wordpress.com/kuliah/teori-pembangunan/gender-danpembangunan/.

${ }^{22}$ Ketidakadilan atau diskriminasi gender merupakan kondisi kesenjangan dan ketimpangan atau tidak adil akibat dari sistem struktur sosial dimana baik perempuan dan laki-laki menjadi korban dari sistem tersebut. Ketidakadilan gender terjadi karena adanya keyakinan dan pembenaran yang ditanamkan sepanjang peradapan manusia dalam berbagai bentuk yang bukan hanya menimpa perempuan saja tetapi juga dialami oleh laki-laki.Meskipun secara keseluruhan ketidakadilan gender dalam berbagai kehidupan lebih banyak dialami oleh kaum perempuan, namun ketidakadilan gender itu berdampak pula terhadap lakilaki. 
kelompok terpisah. Hal ini biasa disebut sebagai Women In Development-WID dan Women And Development- WAD. ${ }^{23}$ Kritik terhadap pendekatan ini menuding bahwa pendekatan ini tidak mengurus soal laki-laki, yang lalu mendorong munculnya model yang disebut Gender And Development-GAD), yang lebih berkonsentrasi pada perencanaan dan intervensi proyek yang berfokus pada proses pembangunan yang mentransformasikan relasi gender. Tujuan dari GAD adalah membuat perempuan mampu berpartisipasi secara setara dengan laki-laki dalam menentukan masa depan bersama. Maka dari itu pendekatan kesetaraan gender adalah mengenai laki-laki dan perempuan dan merupakan pendekatan yang lebih komprehensif untuk menganalisis dan merencanakan intervensi pembangunan karena mempertimbangkan situasi dan kebutuhan laki-laki dan perempuan. Kesetaraan gender bertujuan melibatkan laki-laki dan perempuan dalam menyikapi permasalahan mereka terkait pembangunan, mereformasi lembaga-lembaga untuk membangun hak-hak dan peluang yang setara, serta mendorong perkembangan ekonomi yang menguatkan kesetaraan partisipasi. Pendekatan semacam itu bertujuan untuk memperbaiki kesenjangan yang terus ada terkait akses terhadap sumber daya alam dan kemampuan untuk mengemukakan pendapat.

${ }^{23}$ (1) Perempuan Dalam Pembangunan (Women In Development-WID). Pendekatan WID muncul pada dekade 70-an sebagai produk dari gerakan kaum feminis liberal Amerika yang melihat bahwa kaum perempuan diabaikan dan tereksklusi dari program pembangunan. Para penganut pendekatan WID yakin bahwa pembangunan tidak akan terjadi jika perempuan tidak dimasukkan di dalam proses pembangunan. Oleh sebab itu untuk mengatasi marjinalisasi perempuan, mereka memperjuangkan penerapan proyek pembangunan terpisah atau terintegrasi untuk kaum perempuan. Asumsi yang mereka kemukakan adalah jika kaum perempuan mendapat akses pada sumber daya seperti kredit, pelatihan, kegiatan peningkatan penghasilan maka kaum perempuan akan mampu meningkatkan posisinya sejajar dengan laki-laki. Penerapan konsep WID ini ternyata tidak membawa perubahan yang signifikan terhadap partisipasi perempuan dalam pembangunan. Hal ini disebabkan oleh budaya patriarkhi yang membelenggu kebanyakan penduduk negara berkembang, menimbulkan peran sosial budaya dan ekonomi kaum perempuan tersubordinasi oleh laki-laki.(2)Perempuan dan Pembangunan (Women And DevelopmentWAD), Kegagalan pendekatan WID dalam memperjuangkan perbaikan posisi kaum perempuan dalam pembangunan, menyebabkan perlunya pendekatan lain yang disebut pendekatan Perempuan dan Pembagunan (Women And Development-WAD). Para pendukung pendekatan WAD berpendapat bahwa kaum perempuan tidak akan pernah mendapatkan bagian dari manfaat pembangunan yang adil dan merata jika pengaruh budaya patriarkhi belum dapat diatasi. Mereka melihat bahwa mengatasi kemiskinan dan dampak kolonialisme juga penting untuk mempromosikan persamaan gender dalam proses pembangunan. Pendekatan WAD ternyata juga gagal dalam mempengaruhi akses kaum perempuan dalam program pembangunan. (3)Gender dan Pembangunan (Gender And Development-GAD). Kegagalan pendekatan WID dan WAD menyebabkan pada tahun 1980-an muncul pendekatan Gender dan Pembangunan (Gender And Development-GAD). Para pendukung pendekatan GAD melihat bahwa terjadi subordinasi perempuan di bawah pengaruh ayah dan suami mereka. Oleh sebab itu dengan meningkatkan akses perempuan pada layanan publik dapat mengatasi persoalan subordinasi tersebut. Pendukung pendekatan GAD berpendapat bahwa nilai peran produksi (kerja berbayar dan kerja tak berbayar) serta peran reproduksi (melahirkan dan merawat anak) para ibu rumah tangga dapat memberikan manfaat pada rumah tangga dan industri. Tujuan akhir pendekatan GAD adalah terjadinya pergeseran hubungan kekuasaan yang akan memberikan otonomi lebih besar terhadap kaum perempuan. Kesetaraan dan keadilan gender masih sulit untuk dinikmati oleh seluruh lapisan masyarakat khususnya kaum perempuan. Oleh sebab itu pemerintah telah mengambil kebijakan, tentang perlu adanya strategi yang tepat sehingga dapat menjangkau seluruh lapisan masyarakat.dalam Julia Cleves Mosse, Gender \& Pembangunan, (Yogyakarta: Pustaka Pelajar Offset, 2007), h. 202-209. 
Strategi ini disebut Pengarusutamaan Gender (Gender Mainstreaming) yang tertuangdi dalam Instruksi Presiden (Inpres) No. 9tahun 2000 tentang Pengarusutamaan Gender dalam Pembangunan Nasional sampai daerah. Pengarusutamaan gender dapat diartikan sebagai suatu upaya atau strategi yang dibangun untuk mengintegrasikan kebijakan gender dalam program pembangunan mulai dari perencanaan, pelaksanaan, pemantauan (monitoring) dan evaluasi. Pengarusutamaan Gender, bertujuan untuk terselenggaranya perencanaan, pelaksanaan, pemantauan dan evaluasi atas kebijakan dan program pembangunan nasional yang berperspektif gender. ${ }^{24}$

\section{F. Dakwah Terhadap Keterlibatan Perempuan dalam Politik}

Perempuan dalam proses kontruksi sosial di masyarakat, peran perempuan bersifat domestik sehingga timbul adanya isuketidakadilan gender atau diskriminasi gender. Namun, perubahan kebijakan melihat kebutuhan bahwa perempuan semakin dituntut untuk memasuki dunia publik karena juga dibutuhkan pemikirannya, sementara laki-laki juga perlu peka dan lebih intensif terlibat pada kegiatan yang bersifat domestik, karena keduanya memiliki nilai yang sama. Linda Amalia Sari Gumelar, Menteri Pemberdayaan Perempuan dan Perlindungan Anak menyatakan bahwa perempuan banyak bekerja di sektor informal yang umumnya tidak tercatat. Padahal peran mereka mencapai 70\% untuk usaha mikro dan kecil. Bahkan dari sisi tenaga kerja Indonesia, 70\% lebih perempuan telah mengirimkan devisa bagi Indonesia atau uang bagi kehidupan keluarganya mencapai US $\$ 5,7$ miliar. Angka ini tentu menjadi menguatkan mengapa keterwakilan perempuan di politik sangat penting untuk memperhatikan masyarakat perempuan di Indonesia yang banyak memberikan kontribusi untuk negara. ${ }^{25}$

Berdasarkan studi kasus di atas, terlihat kuota 30\% perempuan untuk menduduki partai politik memberikan harapan kepada perempuan untuk ikut andil dalam pembangunan. Peran perempuan yang sejatinya, reproduksi (ibu + istri), produksi (pencari nafkah tambahan), masyarakat (pengelolaan masyarakat dan layanan sukarela misalnya menjadi kader kesehatan), dapat juga menyelesaikan problem-problem perempuan dengan adanya kuota 30\%. Kenapa kuotanya 30\%? Kenapa tidak 20\%, 50\%, 70\%, dan sebagainya. Karena perempuan tidak lepas dari peran utamanya sebagai ibu rumah tangga. Peran total diberikan kepada laki-laki, karena peran laki-laki, reproduksi (ayah), produksi (mencari nafkah), dan masyarakat (kepemimpinan, politik, pertahanan, dan seringkali bersifat formal dan dibayar).

\footnotetext{
${ }^{24}$ Waston Malau, “Pengarusutamaan Gender dalam Program Pembangunan”, Jurnal Pendidikan Ilmu-Ilmu Sosial 6 (2) (2014): 125-131, h. 3-6.

${ }^{25}$ Mariana Amiruddin, "Perempuan dan Partai Politik: Fenomena Kuota 30\%," dalam jurnal perempuan pencerahan dan kesetaraan.
} 
Peran gender tersebut tidak harus sama antara laki-laki dan perempuan. Ada wilayah-wilayah yang bisa dilakukan laki-laki tetapi tidak bisa dilakukan perempuan. Misalnya banyak pekerjaan laki-laki yang bisa dilakukan perempuan seperti kenek bus, security, sopir, tukang bangunan, politik, pabrik garmen, pabrik rokok, mall-mall, sekretaris, dan sebagainya sudah banyak yang melibatkan perempuan. Sedangkan pekerjaan yang biasanya dilakukan perempuan bisa dilakukan laki-laki seperti koki, pekerjasalon, dan sebagainya. Peran gender dapat dipertukan dan berubah tergantung kontruksi sosial budaya masyarakat.

Dari elaborasi di atas diketahui bahwa keberadaan perempuan dalam persoalan keadilan peran terhadap laki-laki menjadi penting adanya. perempuan jangan dijadikan sebagai komoditas rumah tangga, sebagai orang "belakang" melainkan dijadikan sebagai partner dalam kegiatan berbagai bidang. Dakwah harus hadir sebagai sebuah upaya meningkatkan peran perempuan, dalam hal ini sebagai sebuah upaya tanpa diskriminasi. Dengan materi dakwah terhadap peran perempuan inilah kemudian dijadikan sebagai sebuah sandaran dalam kehidupan yang lebih baik.

\section{G. Kesimpulan}

Persoalan dalam dakwah dan pembangunan yaitu komunikasi dan partisisipatif masyarakat. Pendapat Ginanjar Kartasasmita (1955) lebih diarahkan pada upaya melakukan dakwah dilaksanakan dengan tanpa membedakan gendernya. Gender sangat berpengaruh dalam dakwah dan pembangunan. Gender dan jenis kelamin(sex)merupakan hal yang berbeda, tetapi mempunyai suatu hubungan yang tidak dapat dipisahkan. Gender sebagai proses 'kontruksi sosial' di dalam masyarakat merupakan pembentukan dari sistem konseptual kebudayaan dan linguistik. Gender juga merupakan alat analisis yang baik untuk memahami persoalan diskriminasi terhadap kaum perempuan secara umum. Ditegaskan bahwa gender adalah pembagian laki-laki dan perempuan yang dikontruksi secara sosial dan budaya. Dan ternyata, perbedaan gender antara laki-laki dan perempuan terjadi melalui proses yang panjang, melalui proses sosialisasi, penguatan, kontruksi, sosial budaya bahkan melalui kekuasaan negara. Peran gender tidak harus sama antara laki-laki dan perempuan, ada wilayah-wilayah yang bisa dilakukan laki-laki tetapi tidak bisa dilakukan perempuan, demikian sebaliknya ada wilayah yang bisa dilakukan perempuan tetapi tidak bisa dilakukan laki-laki, seperti halnya kuota 30\% perempuan dalam parpol. Dakwah terhadap hal ini menjadi penting demi keseimbangan peran, bukan status, antara laki-laki dan perempuan. 


\section{DAFTAR PUSTAKA}

Azra, Azyumardi. Kajian Tematik Al-Qur'an Tentang Kemasyarakatan. Bandung: Angkasa, 2008.

Fakih, M. Analisis Gender dan Transformasi Sosial. Yogyakarta: Pustaka Pelajar, 1996.

Mosse, Julia Cleves. Gender \& Pembangunan. Yogyakarta: Pustaka Pelajar Offset, 2007.

P. Antrobus. The Global Women's Movement. Bangladesh: The University Press, 2004.

RI, Depag.Al-Hidayah (Al-Qur'an Tafsir Per Kata Tajwid Kode Angka). Jakarta: PT Kalim, 2010.

Umar, Nasaruddin. Argumen Kesetaraan Gender Perspektif Al-Qur'an, Jakarta: Paramadina, 2001.

Abdullah, Jihan, "Kesetaraan Gender Dalam Islam", dalam jurnal Musawa, Vol. 1 (1), 2009.

Amiruddin, Mariana, "Perempuan dan Partai Politik: Fenomena Kuota 30\%," dalam jurnal perempuan pencerahan dan kesetaraan.

Fadlan, "Islam, Feminisme, dan Konsep Kesetaraan Gender Dalam Al-Qur'an",dalam Jurnal Karsa, Vol. 19 (2), 2011.

Imoh, Grade 0, "Aplication of Development Communication in Africa's Rural Development-Need for A Paradigm Shift," Global Journal of Arts Humanities and Social Sciences 1, 2013.

Malau, Waston, "Pengarusutamaan Gender dalam Program Pembangunan",Jurnal Pendidikan Ilmu-Ilmu Sosial 6 (2) (2014).

Munawar, Imam, "Komunikasi Partisipatif dalam Proses Pembangunan Pabrik Semen di Desa Tipar Kidul Ajibarang Banyumas", dalam makalah Komunikasi Pembangunan, 2017.

Pasaribu, Vera A. R, "Perempuan dan Pembangunan Nasional Indonesia", dalam karya ilmiah Fakultas Ilmu Sosial dan Ilmu Politik Universitas HKBP nommensen, Medan, 2009.

Pipes, Daniel, "Kata Pengantar: Memahami Wanita Pelaku Bom Bunuh Diri”, dalam artikel asli Foreword Understanding Female Suicide Bombers, 2012.

Puspitawati, Herien, "Konsep, Teori dan Analisis Gender", dalam jurnal Departemen Ilmu Keluarga dan Konsumen Fakultas Ekologi Manusia- Institut Pertanian Bogor 2013.

R. Sinulingga, dalam Jurnal Wawasan, Juni, Volume 12, Nomor 1. Medan: USU 2006.

Aisah, Anisa Siti, dkk, "Gender Sebagai Kontruksi Sosial", diakses Jum'at 10 Juni 2016, dalam http : // tangan-malaikat.blogspot .com/ 2016/ 06/ makalahgender-sebagai-kontruksi-sosial.html?m=1. 
Anonim, “Apa Arti Budaya Patriarki?”, dalam http://id. Answers. yahoo. com/ question/ index?_e_pi_=7\%2CPAG_ID10\%2C3573569691.

Anonim, "Perempuan Kenek Bus," dalam http://remcakram.com.

Anonim, "Perempuan dan Partai Politik: Fenomena Kuota tanpa Kader", dalam http://www.jurnalperempuan.org/perempuan-dan-partai-politikfenomena-kuota-tanpa-kader.html

Anonim, "30 Persen Keterwakilan Perempuan di Parpol Diharapkan hingga Kabupaten," diakses Senin, 28 November 2016 21:12 WIB Kompas TV.

Anonim, "Strategi Komunikasi Pembangunan, dalam http://lalatnasrul.blogspot.co.id/2014/02/strategi-komunikasipembangunan.html.

Maharani, Lailakhamsi,"Peningkatan Partisipasi Dan Keterwakilan Perempuan Di Legislatif, dalam http://sumbarprov.go.id/details/news/4948.

Purba, Orinton, "Konsep dan Teori Gender", diakses 9 Agustus 2010, dalamhttps://gendernews88.wordpress.com/2010/09/07/konsep-danteori-gender/.

Setiawan, Afriandi dkk, Gender dan Pembangunan, diakses 2011, dalam https://arifcintaselvia.wordpress.com/kuliah/teori-pembangunan/genderdanpembangunan/. 